\title{
KEBERHASILAN STEK TANAMAN LAMTORO VARIETAS TARRAMBA (Leucaena leucocephala cv. Tarramba) KARENA PENGARUH UMUR FISIOLOGIS DAN ZAT PENGATUR TUMBUH
}

\author{
Noorwitri Utami, Siti Himawati, Dwi Pangesti Handayani, Maman Surachman, \\ Armelia Tanjung, dan Juwartina Ida Royani \\ Pusat Teknologi Produksi Pertanian BPPT, Tangerang Selatan - Banten \\ e-mail: noorwitri.utami@bppt.go.id
}

\begin{abstract}
ABSTRAK
Lamtoro (Leucaena leucocephala cv Tarramba) merupakan salah satu hjauan pakan tenak yang potensial untuk dikembangkan. Perbanyakan vegetatif dengan stek batang merupakan salah satu alternatif perbanyakan yang memiliki keunggulan dapat dilakukan secara cepat oleh masyarakat dan memliki sifat yang sama dengan induknya. Tujuan penelitian ini adalah untuk mengetahui umur fisiologis dan jenis zat pengatur tumbuh yang terbaik untuk keberhasilan stek tanaman lamtoro. Penelitian dilakukan menggunakan rancangan acak kelompok dua faktor perlakuan dan diulang tiga kali. Faktor pertama umur fisilogis batang terdiri atas tiga taraf yaitu pangkal, tengah dan bagian atas (ujung) batang. Faktor kedua penggunaan zat pengatur tumbuh yang digunakan yang terdiri dari 4 taraf, yaitu: tanpa zat pengatur tumbuh, indole-3-butyric acid (IBA), a-naphtaleneacetic acid (NAA) dan root up. Hasil penelitian menunjukkan umur fisiologis batang dan zat pengatur tumbuh berpengaruh nyata terhadap keberhasilan stek lamtoro, namun interaksi antara kedua faktor perlakuan tidak terdapat pengaruh nyata terhadap semua peubah yang diamati. Keberhasilan stek dari batang bagian pangkal $(88,10 \%)$ lebih tinggi dibandingkan batang bagian tengah dan ujung masing-masing 82,14\% dan 35,71\%. Penggunaan zat pengatur tumbuh IBA, NAA dan Root Up memberikan persentase stek lamtoro hidup yang lebih tinggi dibandingkan tanpa penggunaan zat pengatur
\end{abstract}

Kata kunci: auksin, leguminosa, Leucaena leucocephala cv Tarramba, perbanyakan vegetatif, umur fisiologis

\section{THE SUCCESS OF LAMTORO VARIETY TARRAMBA CUTTING (Leucaena leucocephala cv. Tarramba) AFFECTED BY PHYSIOLOGICAL AGE AND GROWTH REGULATOR}

\begin{abstract}
Lamtoro (Leucaena leucocephala cv Tarramba) is one of the potential forage to be developed. Vegetative propagation with stem cuttings is an alternative propagation that has advantages can be done quickly by the farmers and has the same properties with mother stocks. This study was conducted to determine the best physiological age and type of growth regulators for the success of lamtoro cuttings. This study was conducted using a completely randomized design with two treatment factors and repeated three times. The first factor is the physiological age of the stem consists of three levels, namely the base, middle and the top (tip) of the stem. The second factor is the use of growth regulators used which consists of 4 levels, namely: control (without growth regulator), indole-3-butyric acid (IBA), $\alpha$-naphtaleneacetic acid (NAA) and root up. The results showed that the physiological age of the stem and growth regulators had a significant effect on the success of lamtoro cuttings, but the interaction between the two treatment factors did not significantly affect all observed variables. The success of cuttings from the base stem (88.10\%) was higher than the middle and tip stem respectively $82.14 \%$ and $35.71 \%$. The use of growth regulators IBA, NAA and Root Up gives a higher percentage of live lamtoro cuttings than without the use of growth regulators.
\end{abstract}

Keywords: auksin, leguminosa, Leucaena leucocephala cv Tarramba, vegetatif propagation, physiological age 


\section{PENDAHULUAN}

Keberhasilan peternakan tidak lepas dari ketersediaan pakan ternak. Lamtoro cv Tarramba adalah hijaun pakan dari famili leguminosae yang memiliki keunggulan produksi daun lebih tinggi, tahan kutu locat (Heteropsylla cubana) (Dilaga et al., 2016), tahan pada musim kemarau (Yumiarty dan Suradi, 2010) dan dapat tumbuh cukup baik sampai pH 5,5 (Manpaki et al., 2017). Lamtoro cv Tarramba atau dikenal juga sebagai Leucaena KX2 menghasilkan sedikit biji dan mengalami segregasi pada generasi berikutnya jika ditanam menggunakan biji, sehingga untuk perbanyakannya disarankan menggunakan bahan vegetatif (Dilaga et al., 2016).

Propagasi tanaman secara vegetatif dapat dilakukan menggunakan stek. Keuntungan propagasi secara vegetatif antara lain tanaman yang dihasilkan secara genetik memiliki sifat yang sama dengan tetuanya dan bebas penyakit untuk tanaman komersial tertentu (Nanda dan Kochhar, 1987). Stek batang adalah metode tradisional dan menjanjikan untuk perbanyakan tanaman (Gopale dan Zunjarrao, 2011). Keberhasilan perbanyakan tanaman melalui stek dipengaruhi oleh genotip, umur fisiologis, posisi, serta diameter batang (Islam et al., 2010; Kraiem et al., 2010; Hennig, 2003). Terbentuknya akar dari tanaman berkayu atau tanaman tahunan menurun seiring dengan umur tanaman induknya (Kraiem et al., 2010). Untuk meningkatkan keberhasilannya maka perlu diketahui umur fisiologis batang yang digunakan sebagai bahan stek.

Salah satu indikasi keberhasilan perbanyakan dengan stek adalah terbentuknya akar. Pada beberapa tanaman stek dapat membentuk akar tanpa perlakuan apapun, sedangkan pada tanaman yang lain memerlukan zat pengatur tumbuh untuk menginduksi perakaran. Salah satu upaya untuk meningkatkan keberhasilan stek pada tanaman adalah dengan pemberian auksin. Aplikasi auksin pada stek dapat mempercepat pembentukan akar (Guo et al., 2009).

Penelitian ini bertujuan untuk meningkatkan keberhasilan stek tanaman lamtoro cv Tarramba melalui pemilihan umur fisiologis batang dan pemberian jenis auksin yang lebih efektif.

\section{MATERI DAN METODE}

Penelitian berlangsung pada bulan September - November 2019 di Rumah Kaca Pusat Teknologi Produksi Pertanian BPPT, Puspiptek, Tangerang Selatan . Bahan penelitian yang digunakan dalam penelitian ini adalah tanaman lamtoro cv Tarramba yang telah berumur enam bulan, polibag, media tanam berupa campuran tanah dan pupuk kandang dengan perbandingan 1: 1, bakterisida (Agrept 20WP), fungisida (Dithane M-45), ZPT auksin yaitu IBA, NAA dan root up. Alat-alat yang digunakan selama penelitian yaitu gunting stek, gembor, sungkup plastik, penggaris dan timbangan.

Penelitian ini menggunakan rancangan acak kelompok dengan dua faktor perlakuan. Faktor pertama adalah umur fisiologis batang yang digunakan sebagai sumber stek yang terdiri dari tiga taraf yaitu bagian pangkal, tengah dan ujung batang. Faktor kedua adalah penggunaan zat pengatur tumbuh auksin yaitu kontrol/tanpa zat pengatur tumbuh, indole-3-butyric acid (IBA), $\alpha$-naphtaleneacetic acid (NAA) dan root up. Setiap perlakuan dikombinasikan sehingga terdapat 12 kombinasi pelakuan. Setiap perlakuan diulang tiga kali, sehingga terdapat 36 satuan percobaan. Setiap satuan percobaan terdiri atas 7 tanaman.

Pelaksanaan penelitian dimulai dengan pengisian media tanam ke dalam polibag. Pengambilan bahan stek dilakukan di pagi hari. Batang tanaman lamtoro dipotong menjadi 3 bagian (pangkal, tengah dan ujung), setiap bagian terdapat 3 ruas dan semua daun pada ruas dihilangkan. Semua bagian stek direndam pada bagian pangkal menggunakan campuran fungisida dan bakterisida $2 \%$ selama 15 menit. Stek tanpa perlakuan zat pengatur tumbuh langsung ditanam ke polibag. Stek dengan perlakuan IBA dan NAA dicelupkan ke dalam larutan berbentuk pasta (100 ppm), sedangkan stek dengan perlakuan root up dicelupkan ke dalam pasta root up. Selanjutnya dilakukan penyiraman secukupnya dan diletakkan dalam rumah sungkup plastik selama satu bulan. Setelah itu, dilakukan pembukaan sungkup secara bertahap.

Peubah pengamatan yang diamati antara lain jumlah tunas, panjang tunas $(\mathrm{cm})$, bobot basah daun (g), panjang akar (cm), bobot basah akar (g) dan stek hidup (\%) yang diamati pada tiga bulan setelah tanam. Data yang diperoleh dianalisis menggunakan ANOVA dan jika terdapat beda nyata maka dilanjutkan menggunakan DMRT $5 \%$.

\section{HASIL DAN PEMBAHASAN}

Keberhasilan stek tanaman lamtoro pada penelitian ini dipengaruhi oleh umur fisiologis batang sumber stek dan penggunaan auksin sebagai perangsang pembentukan akar, namun tidak terdapat interaksi yang berpengaruh nyata terhadap peubah yang diamati.

\section{Pengaruh Umur Fisiologis Batang terhadapStek Tanaman Lamtoro}

Perbedaan umur fisiologis batang sebagai sumber stek berpengaruh nyata terhadap panjang tunas dan bobot basah daun, namun tidak berbeda nyata 
terhadap jumlah tunas yang tumbuh (Tabel 1). Bibit hasil stek batang pada bagian tengah dan pangkal menghasilkan panjang tunas yang lebih tinggi dibandingkan pada batang bagian ujung, masingmasing sebesar $35,19 \%$ dan $52,31 \%$. Bobot basah daun pada bibit hasil stek batang bagian tengah dan pangkal juga lebih besar dibandingkan pada bibit hasil stek batang bagian ujung secara berurutan sebesar $34,59 \%$ dan $47,79 \%$.

Tabel 1. Rata-rata Jumlah Tunas, Panjang Tunas dan Bobot Basah Daun Karena Pengaruh Umur Fisiologis Batang

\begin{tabular}{lccc}
\hline $\begin{array}{c}\text { Umur fisiologis } \\
\text { batang }\end{array}$ & Jumlah tunas & $\begin{array}{c}\text { Panjang tunas } \\
(\mathrm{cm})\end{array}$ & $\begin{array}{c}\text { Bobot basah } \\
\text { daun }(\mathrm{g})\end{array}$ \\
\hline Ujung & 1,97 & $31,14^{\mathrm{a}}$ & $1,59^{\mathrm{a}}$ \\
Tengah & 1,86 & $42,10^{\mathrm{b}}$ & $2,14^{\mathrm{ab}}$ \\
Pangkal & 1,58 & $47,43^{\mathrm{b}}$ & $2,35^{\mathrm{b}}$ \\
\hline
\end{tabular}

Keterangan:

*Huruf berbeda pada kolom yang sama menunjukkan berbeda nyata pada taraf $5 \%$ uji DMRT

Umur fisiologis batang sumber stek berpengaruh nyata terhadap bobot basah akar dan persentase stek yang hidup, namun tidak berpengaruh nyata terhadap panjang akar yang terbentuk (Tabel 2). Bobot basah akar pada stek bagian ujung dan tengah lebih rendah sebesar 48,48\% dan 27,27\% dibandingkan bobot basah akar pada stek bagian pangkal. Persentase stek hidup dari batang bagian tengah dan pangkal lebih tinggi dibandingkan bagian ujung secara berurutan sebesar $130 \%$ dan $147 \%$.

Tabel 2. Rata-rata Panjang Akar, Bobot Basah Akar dan Persentase Stek Hidup karena Pengaruh Umur Fisiologis Batang

\begin{tabular}{lccc}
\hline $\begin{array}{c}\text { Umur fisiologis } \\
\text { batang }\end{array}$ & $\begin{array}{c}\text { Panjang akar } \\
(\mathrm{cm})\end{array}$ & $\begin{array}{c}\text { Bobot basah } \\
\text { akar }(\mathrm{g})\end{array}$ & $\begin{array}{c}\text { Stek hidup } \\
(\%)\end{array}$ \\
\hline Ujung & 14,95 & $0,17^{\mathrm{a}}$ & $35,71^{\mathrm{a}}$ \\
Tengah & 20,01 & $0,24^{\mathrm{a}}$ & $82,14^{\mathrm{b}}$ \\
Pangkal & 20,30 & $0,33^{\mathrm{b}}$ & $88,10^{\mathrm{b}}$ \\
\hline
\end{tabular}

Keterangan:

*Huruf berbeda pada kolom yang sama menunjukkan berbeda nyata pada taraf $5 \%$ uji DMRT

Perlakuan umur fisiologis batang pada bagian pangkal dan tengah secara nyata memberikan hasil yang terbaik dibandingkan hasil stek dari bagian ujung. Hal ini dapat dijelaskan karena auksin diproduksi tanaman pada bagian apikal (pucuk tanaman) dan ditranslokasikan secara basipetal, sehingga dimungkinkan bahwa konsentrasi auksin endogen pada bagian pangkal dan tengah batang lebih tinggi dibandingkan pada bagian ujung dan mengakibatkan keberhasilan stek lamtoro bagian pangkal dan tengah lebih tinggi dibandingkan pada bagian ujung.

Hartmann et al. (2002) menuliskan bahwa pertumbuhan akar dan tunas serta persentase keberhasilan pada stek sangat ditentukan oleh jenis bahan stek yang digunakan dan umur fisiologis/posisi bahan stek yang digunakan. Bagian yang digunakan berkaitan dengan status nutrisi dalam bahan stek terutama karbohidrat, protein, lipid, nitrogen, enzim, zat pengatur tumbuh dan rooting cofactor. Hartmann et al. (2002) juga menambahkan bahwa bahan stek dengan rasio $\mathrm{C} / \mathrm{N}$ yang tinggi akan menghasilkan akar yang banyak dengan tunas yang lemah, sebaliknya rasio $\mathrm{C} / \mathrm{N}$ yang rendah akan menghasilkan akar yang sedikit dan tunas yang kuat.

\section{Pengaruh Zat Pengatur Tumbuh terhadap Stek Tanaman Lamtoro}

Propagasi lamtoro cv Tarramba tanpa penggunaan auksin menunjukkan hasil yang paling rendah untuk seluruh peubah hasil penyetekkan (jumlah tunas, panjang tunas, bobot basah daun, panjang akar, bobot basah akar dan persentase stek hidup) (Tabel 3 dan 4). Tidak terdapat perbedaan yang nyata terhadap semua peubah yang diamati dengan aplikasi jenis auksin (IBA, NAA ataupun root up). Penggunaan auksin tunggal (IBA atau NAA) maupun penggunaan auksin komersial (root up) mampu meningkatkan keberhasilan stek hidup lamtoro cv Tarramba antara $25-30.56 \%$ dibandingkan tanpa penggunaan auksin (Tabel 4).

Tabel 3. Rata-rata Jumlah Tunas, Panjang Tunas dan Bobot Basah Daun karena Pengaruh Zat Pengatur Tumbuh

\begin{tabular}{lccc}
\hline $\begin{array}{c}\text { Zat Pengatur } \\
\text { Tumbuh }\end{array}$ & Jumlah tunas & $\begin{array}{c}\text { Panjang tunas } \\
(\mathrm{cm})\end{array}$ & $\begin{array}{c}\text { Bobot basah } \\
\text { daun }(\mathrm{g})\end{array}$ \\
\hline Tanpa ZPT & 1,66 & $27,26^{\mathrm{a}}$ & $1,26^{\mathrm{a}}$ \\
IBA & 1,83 & $48,12^{\mathrm{b}}$ & $2,47^{\mathrm{b}}$ \\
NAA & 1,85 & $42,08^{\mathrm{b}}$ & $2,22^{\mathrm{b}}$ \\
Root up & 1,87 & $43,43^{\mathrm{b}}$ & $2,17^{\mathrm{b}}$ \\
\hline
\end{tabular}

Keterangan:

*Huruf berbeda pada kolom yang sama menunjukkan berbeda nyata pada taraf $5 \%$ uji DMRT

Tabel 4. Rata-rata Panjang Akar, Bobot Basah Akar dan Persentase Stek Hidup karena Pengaruh Zat Pengatur Tumbuh

\begin{tabular}{lccc}
\hline $\begin{array}{c}\text { Zat Pengatur } \\
\text { Tumbuh }\end{array}$ & $\begin{array}{c}\text { Panjang akar } \\
(\mathrm{cm})\end{array}$ & $\begin{array}{c}\text { Bobot basah } \\
\text { akar (g) }\end{array}$ & Stek hidup (\%) \\
\hline Tanpa ZPT & $11,66^{\mathrm{a}}$ & $0,14^{\mathrm{a}}$ & $57,14^{\mathrm{a}}$ \\
IBA & $22,62^{\mathrm{b}}$ & $0,32^{\mathrm{b}}$ & $71,43^{\mathrm{b}}$ \\
NAA & $21,12^{\mathrm{b}}$ & $0,26^{\mathrm{b}}$ & $71,43^{\mathrm{b}}$ \\
Root up & $18,28^{\mathrm{b}}$ & $0,25^{\mathrm{b}}$ & $74,60^{\mathrm{b}}$ \\
\hline
\end{tabular}

Keterangan:

*Huruf berbeda pada kolom yang sama menunjukkan berbeda nyata pada taraf $5 \%$ uji DMRT

Aplikasi auksin sebagai zat pengatur tumbuh penginduksi perakaran telah lama digunakan. IBA dan NAA adalah auksin yang paling efektif dan banyak digunakan dan untuk mendorong 
pembentukan akar pada stek batang (Zimmerman dan Wilcoxon, 1935). Root up merupakan salah satu merk dagang zat pengatur tumbuh yang biasa digunakan sebagai sumber auksin pada proses penyetekkan. Bahan aktif yang terkandung dalam root up antara lain 1-naphtalene-acetamide $0.20 \%$, 2-methyl-1-naphtalene-aceticacid 0,03\%, indol-3butirat $0,06 \%$ serta thiram 4,0\%. Aplikasi root up terhadap stek batang akan menyediakan auksin yang dapat meningkatkan keberhasilan penyetekkan. Hal ini pernah dilaporkan pada tanaman Indigofera sp. (Kurnia, 2019), dan Vernonia elliptica (Prasetyaningsih dan Sitawati, 2019).

\section{SIMPULAN}

Keberhasilan perbanyakan tanaman lamtoro cv Tarramba melalui stek batang dipengaruhi oleh umur fisiologis batang dan penggunaan zat pengatur tumbuh auksin. Penggunaan batang bagian tengah dan pangkal serta penggunaan auksin mampu meningkatkan keberhasilan stek batang.

\section{DAFTAR PUSTAKA}

Dilaga, S. H., Imran, S. Nururly, dan Padusung. 2016. Lamtoro Sumber Pakan Potensial. Pustaka Reka Cipta.

Ferreira, B. G. A., Zuffellato-Ribas K. C., Wendling I., Koehler H.S., and Nogueira A. C. Miniestaquia de Sapium glandulatum (Vell.) Pax com o uso de ácido indol butírico e ácido naftaleno acético. Ciência Florestal. 2010; 20:19-31

Gopale K. D. and R. S. Zunjarrao. 2011. Effect of auxin, length of stem cutting, substrate, and seasonal variations on Jatropha curcas L.: A biodiesel plant. Bioscience Discovery. 02(1):76-81.

Guo, X. F., X. L. Fu, D. K. Zang, and Y. Ma. 2009. Effect of auxin treatments, cuttings, collection date and initial characteristics on Paeonia 'Yang Fei Chu Yu' cutting propagation. Sci. Hort. 199: 177-181.

Hartmann, H. T., D. E. Kester, F. T. Davies, Jr., and R. L. Geneve. 2002. Hartmann and Kester's Plant Propagation: Principles and Practices. 7 th ed. Prentice Hall, Upper Saddle River, NJ.

Henning, R. 2003. The Jatropha booklet, A guide to the jatropha system and its dissemination in Zambia, GTZASSP-Project Zambia, 13, Mazabuka.
Islam A. K. M. A., Z. Yakoob, N. Anuar, and M. Osman. 2010. Propagation potentials of genotypes and different physiological ages of stem cuttings in Jatropha curcas L. J Agric. Sci. 2(4): 75-82.

Kibbler H., M. E. Johnston, and R. R. Williams. 2004. Adventitious root formation in cuttings of Backhousia citriodora F. Muell - 1. Plant genotype, juvenility and characteristics of cuttings. Scientia Horticulturae, 102: 133-143

Kraiem, Z., W. Aidi Wannes, A. Zairi, and B. Ezzili. 2010. Effect of cutting date and position on rooting ability and fatty acid composition of Carignan (Vitis vinifera) shoot. Sci. Hortic. 125:146-150.

Kurnia, I., 2019. Pengaruh jumlah mata tunas dan pemberian dua zat pengatur tumbuh terhadap pertumbuhan stek tanaman Indigofera sp. Bandar Lampung [Skripsi]

MacDonald, B. 1987. Practical Woody Plant Propagation for Nursery Growers. Timber Press, Portland, OR.

Manpaki, S. J., P. D. M. H. Karti, dan I. Prihatoro. Respon pertumbuhan eksplan tanaman lamtoro (Leucaena leucocephala cv. Tarramba) terhadap cekaman kemasaman media dengan level pemberian aluminium melalui kultur jaringan. $J$ Sains Peternakan Indonesia. 12(1): 71-82.

Nanda, K. K., and V. K. Kochhar. 1987. Vegetative Propagation of Plants. Principles and Practices, India Book Trust.

Prasetyaningsih, D. D., dan Sitawati. 2019. Pengaruh posisi penanaman dan pemberian zat pengatur tumbuh terhadap keberhaslan pertumbuhan stek batang tanaman Lee Kwan Yew (Vernonia elliptica). J Produksi Tanaman. 7(1): 173-180.

Weaver, R. J. 1972. Plant Growth Substances in Agriculture. Mc Millan Publishing Co Inc. New York.

Wilson, P. J. 1993. Propagation characteristics of Eucalytus globules Labill. spp. globules stem cutting in relation to their original position in the parent shoot. J. of Hort. Sci. 68(5):715-724. 72.

Yumiarty, H. K., dan K. Suradi. 2010. Utilzation of lamtoro leaf $\mathrm{n}$ diet on pet production and the lose of hair rabbit,s pelt. Jurnal lmu ternak. 7(1): 73-77.

Zimmerman, P. W. and F. Wilcoxon. 1935. Several chemical growth substances which cause initiation of roots and other responses in plants. Contrib. Boyce Thomp. Inst. 7:209-229. 